\title{
Fitoremediasi Air yang Tercemar Limbah Laundry dengan Menggunakan Kayu apu (Pistia
}

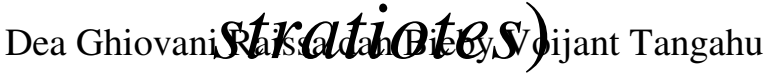

Departemen Teknik Lingkungan, Fakultas Teknik Sipil dan Perencanaan, Institut Teknologi Sepuluh Nopember (ITS)

e-mail: voijant@its.ac.id

\begin{abstract}
Abstrak-Dampak negatif dari limbah laundry yaitu adanya pencemar limbah cair yang dihasilkan dari sisa proses pencucian baju sehingga menyebabkan kekeruhan dan menghalangi sinar matahari masuk ke dalam air yang akan mengakibatkan eutrofikasi. Tumbuhan yang digunakan dalam penelitian ini adalah Kayu apu. Tujuan dari penelitian ini adalah menentukan kemampuan tumbuhan Kayu apu (Pistia stratiotes) dalam menurunkan kandungan organik dalam limbah laundry dan menentukan kerapatan yang optimum pada tumbuhan Kayu apu (Pistia stratiotes) terhadap penurunan limbah laundry. Hasil penelitian ini menunjukkan bahwa tumbuhan Kayu apu mampu menyisihkan BOD sebesar $98 \%$ atau setara dengan $6 \mathrm{mg} / \mathrm{L}$, COD sebesar $96 \%$ atau setara dengan $17 \mathrm{mg} / \mathrm{L}$, fosfat sebesar $99 \%$ atau setara dengan $0,07 \mathrm{mg} / \mathrm{L}$ pada kerapatan $35 \mathrm{mg} / \mathrm{cm}^{2}$. Dalam penelitian ini kerapatan tumbuhan yang digunakan yaitu 14 $\mathrm{mg} / \mathrm{cm}^{2}, 25 \mathrm{mg} / \mathrm{cm}^{2}, 35 \mathrm{mg} / \mathrm{cm}^{2}$. Dari hasil penelitian didapat, tumbuhan Kayu apu dengan kerapatan $35 \mathrm{mg} / \mathrm{cm}^{2}$ memiliki efisiensi removal yang tertinggi.
\end{abstract}

Kata Kunci-BOD, COD, Deterjen, Fitoremediasi, Fosfat, Kayu apu.

\section{PENDAHULUAN}

$\mathrm{P}$ ADA saat ini jasa pencucian pakaian atau laundry berkembang dimana-mana terutama di daerah pemukiman, dimana banyak masyarakat yang tidak sempat mencuci pakaiannya sendiri karena kesibukannya. Air limbah yang dihasilkan langsung disalurkan ke saluran drainase yang pada akhirnya akan mengalir ke badan air. Debit limbah cair yang dihasilkan berfluktuasi tergantung jumlah pelanggan yang mencuci pakaiannya dengan rata-rata effluent sebanyak 550 L/hari [1]. Dampak negatif dari limbah laundry yaitu adanya pencemar limbah cair yang dihasilkan dari sisa proses pencucian baju sehingga mengakibatkan kekeruhan

dan menghalangi sinar matahari masuk ke dalam air.

Kandungan bahan pencemar yang terdapat dalam air limbah laundry dapat menimbulkan dampak negatif pada kehidupan biota sehingga berakibat terjadinya pencemaran pada badan air tersebut. Bahan aktif yang banyak terkandung pada pelembut pakaian dan deterjen adalah kwaterner ammonium klorida, LAS, sodium dodecyl benzene sulfonate, natrium karbonat, natrium fosfat, alkilbenzena sulfonate. Bahan-bahan tersebut merupakan bahan yang ramah lingkungan dan biodegradable. Namun bila keberadaannya di badan air berlebihan, limbah laundry berpotensi mencemari badan air. Hal tersebut dapat menyebabkan eutrofikasi [2] dimana badan air menjadi kaya akan nutrien terlarut, menurunnya kandungan oksigen terlarut dan kemampuan daya dukung badan air terhadap biota air.

Mengingat kondisi badan air semakin hari semakin buruk akibat perilaku manusia, maka sudah seharusnya bila limbah laundry menjalani pengolahan dahulu sebelum dibuang ke badan air. Hal ini diharapkan agar sungai sebagai badan air pertama yang memperoleh beban pencemar tidak semakin menurun kualitasnya. Pengolahan dapat dilakukan dengan berbagai cara, salah satunya yaitu dengan memanfaatkan tumbuhan air untuk menanggulangi jumlah pencemar dengan cara menyerap, mengumpulkan dan mendegradasi bahanbahan pencemar tertentu yang terdapat dalam limbah tersebut yang dikenal dengan fitoremediasi.

Kayu apu (Pistia stratiotes L.) adalah salah satu tumbuhan fitoremediator yaitu tumbuhan yang memiliki kemampuan untuk mengolah limbah, baik itu berupa logam berat, zat organik maupun anorganik. Manfaat tumbuhan air seperti kayu apu dapat mengurangi konsentrasi limbah cair dalam limbah dapat dilakukan dengan proses fitoremediasi [3]. Dari hasil penelitian [4] diketahui bahwa tanaman air seperti kayu apu dapat menurunkan kadar pencemaran limbah cair.

\section{METODE PENELITIAN}

\section{A. Tahap Propagasi}

Tahap propagasi tumbuhan dapat disebut dengan tahap memperbanyak tumbuhan. Pada tahap propagasi ini berfungsi untuk menyediakan stok tumbuhan yang akan digunakan pada saat penelitian. Selama masa propagasi akan dilakukan pengamatan terhadap laju pertumbuhan tumbuhan (growth rate) dan dibiarkan sampai tumbuh tunas (second generation). Tumbuhan yang menjadi second generation inilah yang akan digunakan digunakan pada setiap tahapan penelitian.

\section{B. Tahap Aklimatisasi}

Tahap aklimatisasi tumbuhan dilakukan supaya tumbuhan dapat menyesuaikan dengan kondisi yang akan digunakan untuk tahap RFT (Range Finding Test) dan uji fitoremediasi. Proses aklimatisasi ini dilakukan selama 7 hari. Tumbuhan yang hidup dalam keadaan tidak mati dan tidak layu dipilih untuk digunakan pada uji RFT dan uji fitoremediasi. 


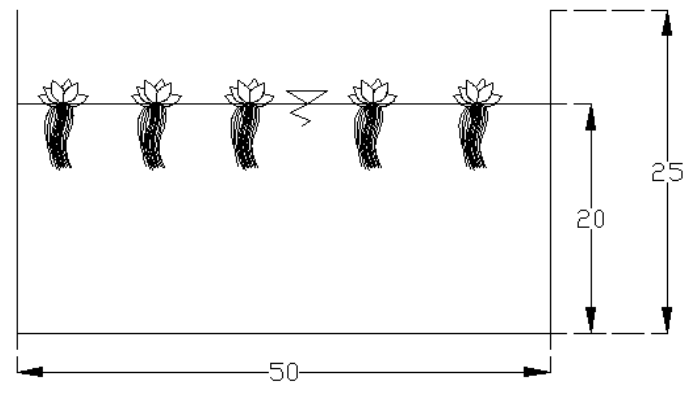

Gambar 1. Reaktor uji fitoremediasi tumbuhan kayu apu.

\section{A. RFT (Range Finding Test)}

Pada RFT ini dilakukan variasi konsentrasi untuk mengetahui seberapa besar kemampuan tumbuhan dalam menyerap polutan pada konsentrasi tertentu. Variasi konsentrasi yang digunakan yaitu $0 \%$ (kontrol), 10\%, 20\%, $40 \%, 60 \%, 80 \%$, kemudian konsentrasi diturunkan menjadi $0 \%$ (kontrol), 20\%, 25\%, 30\%, 35\%, $40 \%$.

\section{B. Uji Fitoremediasi}

Penelitian dilakukan dengan sistem batch dan dilakukan secara duplo. Menggunakan variasi jenis tumbuhan dan kerapatan tumbuhan. Kemudian menambahkan air limbah yang telah disiapkan ke setiap masing-masing variasi pada reaktor

\section{HASIL DAN PEMBAHASAN}

\section{A. Uji Karakteristik Limbah}

Limbah yang akan digunakan adalah limbah laundry. Limbah diambil dari salah satu usaha laundry yang terdapat di daerah Keputih, Surabaya. Hasil uji karakteristik limbah laundry dapat dilihat pada Tabel 1.

Berdasarkan hasil analisis awal didapatkan nilai BOD sebesar $397 \mathrm{mg} / \mathrm{L}$, COD sebesar $464 \mathrm{mg} / \mathrm{L}$ dan fosfat sebesar $10,3 \mathrm{mg} / \mathrm{L}$. Untuk nilai BOD, COD dan fosfat masih melebihi dari baku mutu bagi usaha/ kegiatan laundry menurut Peraturan Gubernur Jawa Timur no. 72 tahun 2013, tetapi untuk nilai $\mathrm{pH}$ masih memenuhi baku mutu.

\section{B. RFT (Range Finding Test)}

Pada tahap ini akan diketahui batas kritis konsentrasi yang tidak memberi efek kematian pada tumbuhan. Konsentrasi inilah yang akan digunakan pada saat penelitian utama. Variasi konsentrasi yang digunakan yaitu $0 \%$ (kontrol), 10\%, 20\%, $40 \%, 60 \%, 80 \%$. Tumbuhan yang digunakan adalah hasil dari aklimatisasi sebelumnya, hal ini diharapkan supaya tumbuhan dapat beradaptasi dengan media yang akan digunakan. Dari hasil pengamatan selama 7 hari terlihat bahwa Kayu apu mampu hidup dengan baik pada konsentrasi limbah sebesar $20 \%$ yang setara dengan $79,4 \mathrm{mg} / \mathrm{L} \mathrm{BOD}, 92,8 \mathrm{mg} / \mathrm{L}$ COD, dan 2,06 mg/L fosfat. Pada konsentrasi 30\% sampai 50\% Kayu apu tidak dapat hidup dengan baik. Pengamatan secara fisik pada tumbuhan dapat dilihat pada Gambar 2.

RFT dilakukan dua kali dikarenakan range konsentrasi pada tahap RFT pertama yaitu sebesar $20 \%-40 \%$, diharapkan pada
Tabel 1.

Hasil Uji Karakteristik Limbah Laundry

\begin{tabular}{llccc}
\hline \hline No. & Parameter & Satuan & Hasil Analisis & $\begin{array}{c}\text { Baku } \\
\text { Mutu }\end{array}$ \\
\hline 1. & BOD & $\mathrm{mg} / \mathrm{L}$ & $397 \pm 81,4$ & 100 \\
2. & $\mathrm{COD}$ & $\mathrm{mg} / \mathrm{L}$ & $464 \pm 85,9$ & 250 \\
3. & Fosfat & $\mathrm{mg} / \mathrm{L}$ & $10,3 \pm 3,04$ & 10 \\
4. & $\mathrm{pH}$ & & 7,21 & $6-9$ \\
\hline \hline
\end{tabular}

*Kep. Gubernur Jawa Timur no. 72/2013.

range tersebut terdapat beberapa tumbuhan Kayu apu mengalami kematian. Range konsentrasi diturunkan menjadi $0 \%$ (kontrol), 20\%, 25\%, 30\%, 35\%, dan 40\%. Dari hasil pengamatan selama 7 hari, terlihat bahwa tumbuhan Kayu apu mampu hidup dengan baik pada konsentrasi limbah sebesar $20 \%$ yang setara dengan 79,4 mg/L BOD, 92,8 mg/L COD, dan 2,06 mg/L fosfat. Pada konsentrasi 25\% hingga 40\% Kayu apu tidak dapat hidup dengan baik. Pengamatan secara fisik pada tumbuhan dapat dilihat pada Gambar 3

\section{Uji Fitoremediasi}

Penelitian utama yaitu tahap uji fitoremediasi ini adalah dengan sistem batch. Tumbuhan yang digunakan adalah tumbuhan yang sudah melalui tahap aklimatisasi sebelumnya, supaya tumbuhan sudah beradaptasi dengan kondisi yang akan digunakan dalam uji fitoremediasi.

Konsentrasi limbah yang digunakan adalah konsentrasi limbah hasil RFT yang tidak menimbulkan efek kematian pada tumbuhan. Konsentrasi limbah laundry yang digunakan yaitu $20 \%$ (v/v) untuk tumbuhan Kayu apu. Konsentrasi ini merupakan konsentrasi yang tidak menimbulkan efek kematian pada tumbuhan Kayu apu.

Variasi pada penelitian ini yaitu variasi pada kerapatan tumbuhan. Untuk kerapatan yang digunakan yaitu $14 \mathrm{mg} / \mathrm{cm}^{2}$, $25 \mathrm{mg} / \mathrm{cm}^{2}$ dan $35 \mathrm{mg} / \mathrm{cm}^{2}$ yang dilakukan selama 20 hari. Waktu pengujian parameter dilakukan saat pagi pukul 06.00 dan sore hari pukul 18.00. Pengambilan sampel dilakukan 1 hari $2 \mathrm{x}$ bertujuan untuk mengetahui kandungan limbah saat tumbuhan sebelum dan sesudah terpapar sinar matahari, dimana pada saat intensitas cahaya sangat tinggi (disaat siang hari) reaksi fotosintesis berjalan lebih besar daripada waktu lainnya karena banyaknya persediaan cahaya matahari.

\section{1) Analisis Parameter $C O D$}

Analisis COD merupakan jumlah oksigen yang dibutuhkan untuk mengurai seluruh bahan organik yang terkandung dalam air limbah. Pengambilan sampel dilakukan pada hari ke- 3, 6, 9, 12,15, 18 dan 2. Berikut hasil analisis COD pada masingmasing reaktor, dapat dilihat pada Gambar 4 dan Gambar 5.

Berdasarkan hasil penelitian yang dilakukan, didapatkan data penurunan COD untuk masing-masing reaktor. 


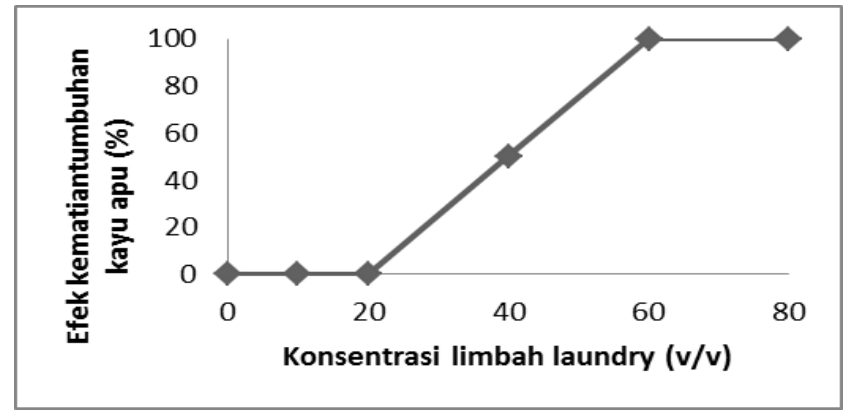

Gambar 2. Lengkung Dosis Limbah Laundry Hasil FRT Kayu apu.

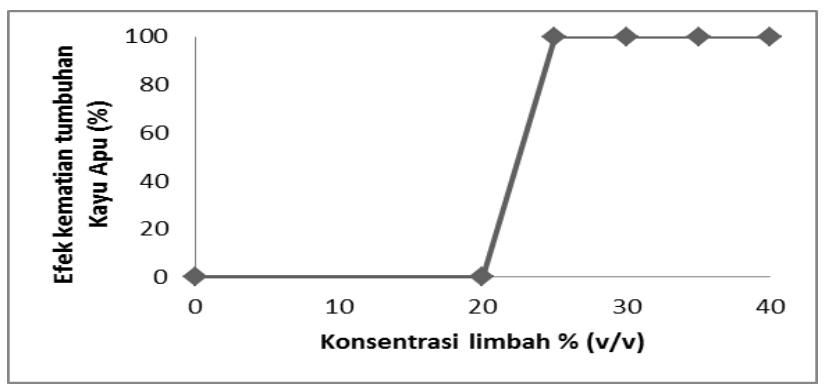

Gambar 3. Lengkung Dosis Limbah Laundry Hasil FRT Kayu apu.

Pada Gambar 4 dan Gambar 5 pengamatan awal yaitu terjadi pada hari ke- 3, tampak bahwa presentasi penyisihan COD pada masing-masing reaktor terjadi kenaikan secara signifikan yaitu reaktor limbah memiliki efisiensi $43 \%$ untuk kerapatan $14 \mathrm{mg} / \mathrm{cm}^{2}, 44 \%$ untuk kerapatan $25 \mathrm{mg} / \mathrm{cm}^{2}, 73 \%$ untuk kerapatan $35 \mathrm{mg} / \mathrm{cm}^{2}$ pada waktu gelap. Sedangkan pada waktu terang, reaktor limbah memiliki efisiensi sebesar 53\% untuk kerapatan $14 \mathrm{mg} / \mathrm{cm}^{2}, 67 \%$ untuk kerapatan $25 \mathrm{mg} / \mathrm{cm}^{2}$, $75 \%$ untuk kerapatan $35 \mathrm{mg} / \mathrm{cm}^{2}$ pada waktu terang. Perbedaan removal pada waktu gelap dan terang hari terjadi kenaikan yang cukup signifikan dikarenakan terjadinya proses fotosintesis, merupakan proses perubahan bahan-bahan anorganik seperti $\mathrm{CO}_{2}$ dan $\mathrm{H}_{2} \mathrm{O}$ oleh klorofil diubah menjadi karbohidrat atas bantuan sinar matahari [5]. Tumbuhan mempunyai peranan yang penting dalam proses pembersihan limbah karena akar tumbuhan merupakan tempat melekatnya [6].

Kenaikan nilai removal COD semakin hari semakin meningkat. Hal ini terjadi karena proses degradasi akan mulai efektif ketika mikroorganisme di dalam zona akar sudah mulai tumbuh dalam jumlah yang banyak [5]. Kenaikan removal pada reaktor uji terjadi karena penguraian bahan organik oleh mikroorganisme pada akar tumbuhan kemudian dimanfaatkan tumbuhan untuk fotosintesis.

1) Analisis Parameter $B O D$

Analisis BOD bertujuan untuk menghitung kebutuhan oksigen yang diperlukan oleh mikroorganisme untuk mengurai seluruh bahan organik yang terkandung dalam limbah. Analisis BOD dilakukan untuk menentukan kekuatan pencemaran dari limbah domestik dan limbah industri. Analisis ini merupakan salah satu analisis terpenting dalam aktivitas pencemaran sungai. Dengan mengetahui nilai BOD memungkinkan untuk menetukan tingkan pencemaran air [7].

Pengambilan sampel dilakukan pada hari ke- 0, 5, 10, 15,

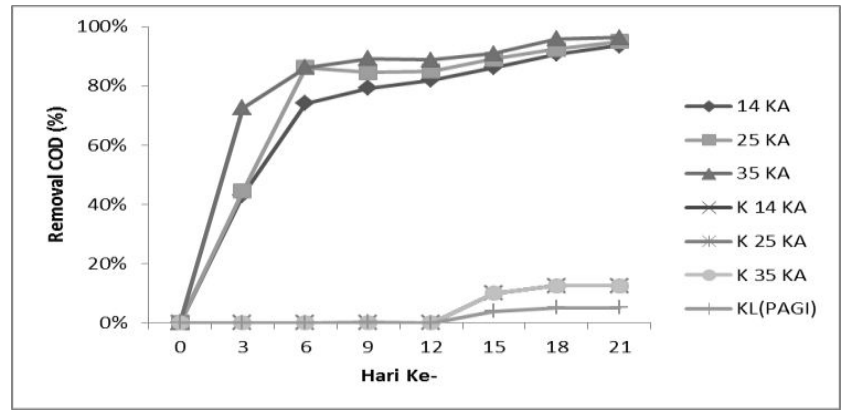

Gambar 4. Removal COD Tumbuhan Kayu apu pada Waktu Gelap.

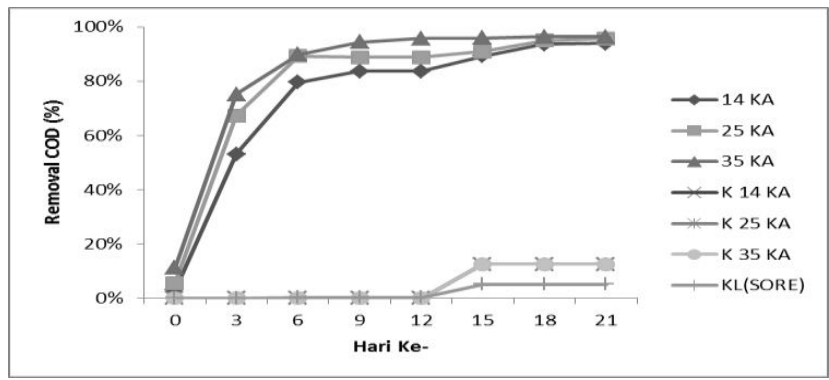

Gambar 5. Removal COD Tumbuhan Kayu apu pada Waktu Terang.

dan 20. Hasil analisis BOD dapat dilihat pada Gambar 6 dan Gambar 7.

Pada pengamatan awal yaitu terjadi pada hari ke- 5, tampak bahwa presentasi penyisihan BOD pada masing-masing reaktor terjadi kenaikan secara signifikan yaitu reaktor limbah memiliki efisiensi sebesar $41 \%$ untuk kerapatan $14 \mathrm{mg} / \mathrm{cm}^{2}$, $46 \%$ untuk kerapatan $25 \mathrm{mg} / \mathrm{cm}^{2}, 75 \%$ untuk kerapatan 35 $\mathrm{mg} / \mathrm{cm}^{2}$ pada waktu gelap. Sedangkan pada waktu terang, reaktor limbah memiliki efisiensi sebesar $62 \%$ untuk kerapata $14 \mathrm{mg} / \mathrm{cm}^{2}, 68 \%$ untuk kerapatan $25 \mathrm{mg} / \mathrm{cm}^{2}, 76 \%$ untuk kerapatan $35 \mathrm{mg} / \mathrm{cm}^{2}$. Hal ini terjadi karena adanya hubungan sinergi terhadap tumbuhan dalam menurunkan zat organik dalam reaktor fitoremediasi, sehingga menyebabkan konsentrasi BOD dalam reaktor tersebut mengalami penurunan. Senyawa organik mudah terurai yang diasosiasikan dengan padatan tersuspensi yang dapat mengendap lebih banyak daripada yang dapat terlarut. Hal ini karena $80 \%$ dari BOD terdiri dari padatan terlarut dan tersuspensi, padatan tersuspensi dapat dibagi menjadi padatan yang dapat mengendap dan yang tidak dapat mengendap (Crites dan Tchobanoglous, 1998). Pada umumnya 60\% dari padatan tersuspensi dalam air limbah domestik adalah padatan yang dapat mengendap [8].

Melalui fitoremediasi, proses penurunan pencemar dalam limbah menggunakan tumbuhan merupakan kerjasama antara tumbuhan dan mikroba yang berada pada tumbuhan tersebut [9]. Kenaikan removal terjadi hampir pada setiap reaktor. Hal ini menunjukkan tumbuhan uji mempunyai peran yang baik dalam mendukung laju penyerapan unsur hara yang ada. Sehingga semakin tinggi aktivitas fotosintesis akan berakibat semakin tinggi pula oksigen terlarut yang dihasilkan yang akan memicu kinerja mikroorganisme dalam meremoval senyawa organik yang ada. 


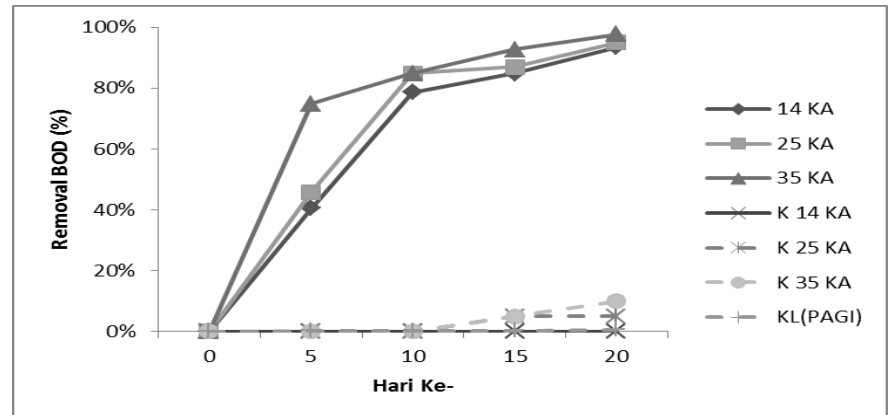

Gambar 6. Removal BOD Tumbuhan Kayu Apu pada Waktu Gelap.

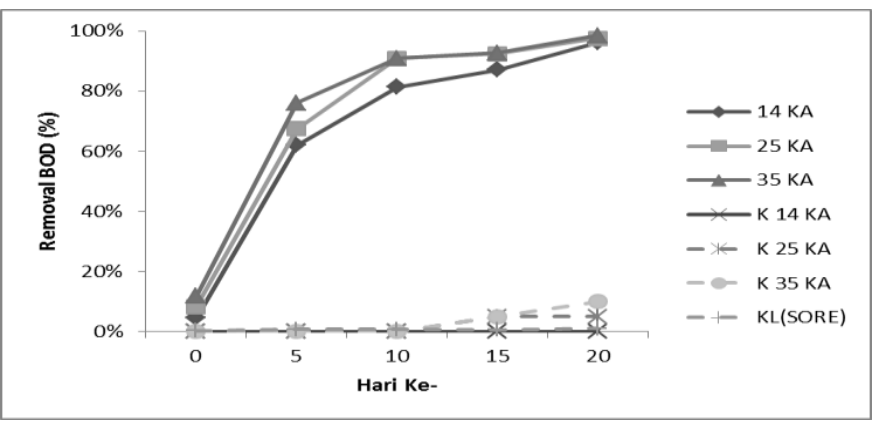

Gambar 7. Removal BOD Tumbuhan Kayu Apu pada Waktu Terang.

Untuk reaktor kontrol juga mengalami kenaikan removal pada hari ke-15 meskipun nilai removal masih berada dibawah nilai removal reaktor uji fitoremediasi, hal ini dikarenakan kandungan organik yang terdapat di dalam reaktor kontrol hanya sedikit, sehingga mikroorganisme yang terdapat di reaktor kontrol tidak seberapa efektif dalam meremoval senyawa organik yang terdapat di dalam reaktor kontrol.

1) Analisis Parameter Fosfat

Pengambilan sampel dilakukan pada hari ke- 3, 6, 9, 12,15, 18 dan 21. Berikut hasil analisis fosfat pada masing-masing reaktor, dapat dilihat pada Gambar 8 dan Gambar 9.

Dapat dilihat pada pada Gambar 8 dan Gambar 9 didapatkan data penurunan fosfat untuk masing-masing reaktor. Pada pengamatan awal yaitu terjadi pada hari ke- 3, tampak bahwa presentasi penyisihan fosfat pada masingmasing reaktor terjadi kenaikan yaitu reaktor limbah memiliki efisiensi sebesar $22 \%$ untuk kerapatan $14 \mathrm{mg} / \mathrm{cm}^{2}, 23 \%$ untuk kerapatan $25 \mathrm{mg} / \mathrm{cm}^{2}, 27 \%$ untuk kerapatan $35 \mathrm{mg} / \mathrm{cm}^{2}$ pada waktu gelap. Sedangkan pada waktu terang, reaktor limbah memiliki efisiensi sebesar $26 \%$ untuk kerapatan $14 \mathrm{mg} / \mathrm{cm}^{2}$, $28 \%$ untuk kerapatan $25 \mathrm{mg} / \mathrm{cm}^{2}, 30 \%$ untuk kerapatan 35 $\mathrm{mg} / \mathrm{cm}^{2}$. Kenaikan nilai dimulai dari pengamatan hari ke- 18 yaitu mencapai $80 \%-99 \%$. Hal ini dikarenakan banyaknya tunas-tunas baru yang muncul pada masing-masing reaktor, sehingga kandungan fosfat dapat berkurang.

Terjadinya proses penguraian oleh mikroorganisme yang terjadi di zona akar atau yang lebih dikenal dengan istilah rizodegradasi [10]. Akar tumbuhan berperan sangat baik menyerap fosfat yang terkandung dalam air limbah [11]]. Sedangkan untuk reaktor kontrol mengalami kenaikan removal meskipun dibawah removal reaktor uji. Ion fosfat merupakan sumber P bagi tanaman. Pada penelitian ini, ion fosfat diambil

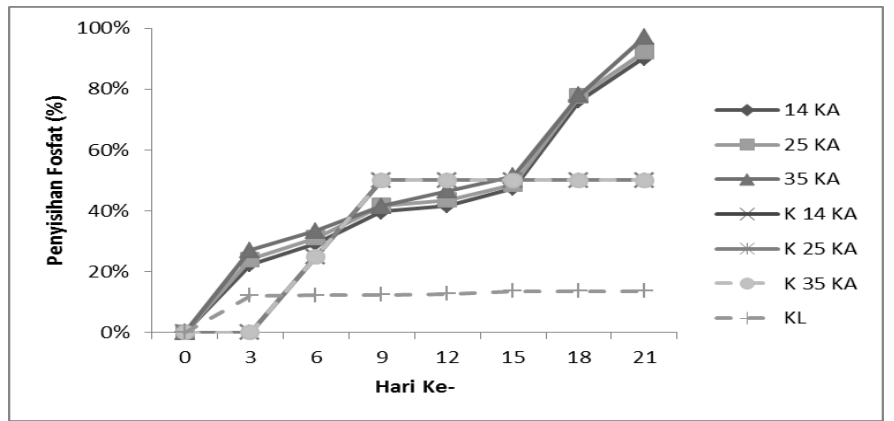

Gambar 8. Penyisihan Fosfat tumbuhan Kayu apu pada Waktu Gelap.

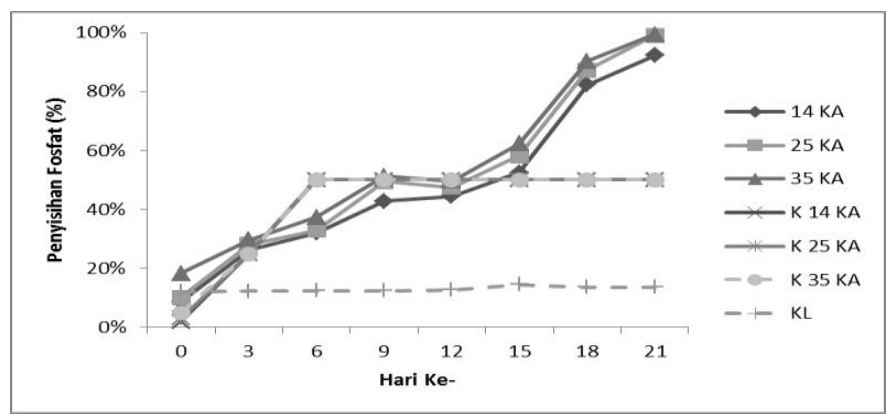

Gambar 9. Penyisihan Fosfat tumbuhan Kayu apu pada Waktu Terang.

oleh akar tumbuhan Kayu apu sebagai nutrisi bagi tanaman sehingga semakin lama tanaman hidup dalam media limbah semakin kecil konsentrasi fosfat dalam limbah [12].

\section{KESIMPULAN}

Berdasarkan hasil penelitian yang telah dilakukan, dapat disimpulkan tumbuhan Kayu apu mampu menyisihkan BOD sebesar $98 \%$ atau setara dengan $6 \mathrm{mg} / \mathrm{L}$, COD sebesar $96 \%$ atau setara dengan $17 \mathrm{mg} / \mathrm{L}$, fosfat sebesar $99 \%$ atau setara dengan $0,07 \mathrm{mg} / \mathrm{L}$ pada kerapatan $35 \mathrm{mg} / \mathrm{cm}^{2}$. Dalam penelitian ini kerapatan tumbuhan yang digunakan yaitu 14 $\mathrm{mg} / \mathrm{cm}^{2}, \quad 25 \mathrm{mg} / \mathrm{cm}^{2}, \quad 35 \mathrm{mg} / \mathrm{cm}^{2}$ Kayu apu. Dari hasil penelitian didapat, tumbuhan Kayu apu dengan kerapatan 35 $\mathrm{mg} / \mathrm{cm}^{2}$ memiliki efisiensi removal yang lebih tinggi.

\section{DAFTAR PUSTAKA}

[1] C. Puspitahati, "Studi Kinerja Biosand Filter dalam Mengolah Limbah Laundy dengan Parameter Fosfat," Surabaya, 2012.

[2] U.S. Enviromental Protection Agency, Compendium of Methods for the Determination of Toxic Organic Compounds in Ambient Air, 2nd ed. 1999.

[3] H. Mamonto, "Uji Potensi Kayu Apu (Pistia stratiotes L) Dalam Penurunan Kadar Sianida (CN) Pada Limbah Cair Penambangan Emas," 2013.

[4] I. Ulfin, Amirudin, and M. P. Zainuddin, "Pengaruh Logam Berat $\mathrm{Pb}$ pada Penyerapan Logam Berat Cd dalam Larutan oleh Kayu Apu (Pistia stratiotes L.)," in Prosiding SENAKI II, 2000.

[5] D. Ningsih, A, "Uji Penurunan Kandungan BOD,COD, dan Warna Pada Limbah Cair Pewarnaan Batik menggunakan Scirpus grossus dan Iris pseudacorus dengan Sistem Pemaparan Intermittent.," Surabaya, 2017.

[6] M. Khiatuddin, "Pelestarian Sumber Daya Air Dengan Teknologi Rawa," Lampung, 2003.

[7] A. Wardhana, W, "Dampak Pencemaran Lingkungan," Yogyakarta, 2001.

[8] Metcalf and Eddy, Wastewater Engineering Treatment and Reuse. New York: Mc Graw Hill, 2003. 
[9] N. Hayati, "Kemampuan eceng gondok dalam mengubah sifat fisik kimia limbah cair pabrik pupuk urea dan asam formiat," Institut Teknologi Bandung, 1992.

[10] S. Mangkoedihardjo and G. Samudro, Fitoteknologi Terapan. Yogyakarta: Graha Ilmu, 2010.

[11] S. Hermawati, E., Wiryanto., "Fitoremediasi Limbah Detergen Menggunakan Kayu Apu (Pistia stratiotes L. ) dan Genjer
(Limnocharis flava L)," vol. 7, no. 2, pp. 115-124, 2005.

T. Padmaningrum and et al, "Pengaruh Biomasa Melati Air (Echinodorus paleafolius) dan Teratai (Nyphaea firecrest) terhadap Kadar Fosfat, BOD, COD TSS dan derajat Keasaman Limbah Cair Laundry," 2014. 